\title{
Erratum to: Scientific revolutions, specialization and the discovery of the structure of DNA: toward a new picture of the development of the sciences
}

\section{Vincenzo Politi ${ }^{1}$}

\section{Erratum to: Synthese DOI 10.1007/s11229-017-1339-6}

Both in the bibliography and in the citation in the text, Michelle Gibbons' article below has been mistakenly attributed to "Gibson." The proper reference to the article should be:

Gibbons, M. (2012). Reassessing discovery: Rosalind Franklin, scientific visualization, and the structure of DNA. Philosophy of Science, 79, 63-80.

The online version of the original article can be found under doi:10.1007/s11229-017-1339-6.

$凶$ Vincenzo Politi

plxvp@bristol.ac.uk

1 Department of Philosophy, University of Bristol, Cotham House, Bristol BS6 6JL, UK 